\title{
Climate Change, Wildfires and Fir Forests in Greece: Perceptions of Forest Managers
}

\section{Ioannis Mitsopoulos ${ }^{1 \Xi}$, Yannis Raftoyannis ${ }^{2}$, Dimitrios Bakaloudis ${ }^{3}$}

${ }^{1}$ The Global Fire Monitoring Center (GFMC), Fire Ecology Research Group c/o Freiburg University, Georges-Köhler-Allee 75, DE-79110 Freiburg, Germany

${ }^{2}$ Central Greece University of Applied Sciences, Department of Forestry, Demokratias 3, GR-36100 Karpenisi, Greece

${ }^{3}$ Aristotle University of Thessaloniki, School of Forestry and Natural Environment, GR-54124, Thessaloniki, Greece

${ }^{\searrow}$ Corresponding author: e-mail: ioanmits@gmail.com

Citation:

MITSOPOULOS I, RAFTOYANNIS Y, BAKALOUDIS D 2015 Climate Change, Wildfires and Fir Forests in Greece: Perceptions of Forest Managers. South-east Eur for 6 (2): 143-157. DOI: http://dx.doi.org/10.15177/seefor.15-12

\section{Abstract}

Background and Purpose: The potential impact that climate change may have on fire regime in ecosystems that are not fire-dependent emerges from fires that are nowadays spreading over higher altitudes and northern latitudes. The effects of fire occurrence in high elevation forests of Greece became apparent during the last few years when a number of large forest fires burned a significant number of high altitude fir ecosystems. This paper describes a study that investigated perceptions of wildfire risk to fir ecosystems of Greece in the context of climate change among a sample of Greek forestry experts by conducting personal interviews.

Materials and Methods: A total of 63 forest experts answered the developed survey from 43 different forest management units covering all forestry agencies which manage fir forests in the country. The perceived fire risk and management to fir forest ecosystems was assessed by means of a subset of scales previously identified as relevant to climate change and to all fire management aspects, such as fire prevention, fire suppression and post fire treatments.

Results: Increased fire risk was rated as a quite important issue in fir forests during the last few years, while the adapting options to climate change are not implemented mainly due to budget and personnel constrains. According to forest experts, fire prevention in fir forests under climate change should be focused on public awareness and fuel management. Nevertheless, the survey results indicate that there is also a need for specific fire prevention measures such as the type of logging activities and other technical measures. The result of this survey highlighted the need for the establishment of a new firefighting organization and for the better coordination of all involved parties during fire suppression. 
Conclusions: The findings of the current study can be critically important in determining how forest fire management considerations are incorporated into forest management plans and policies under climate change.

Keywords: climate change, fir forests, fire management, Greece, survey, wildfires

\section{INTRODUCTION}

Changes in climate, environment and management are altering the world's ecosystems. Forests are of particular importance in this context due to the significant economic, ecological and cultural services they provide. Forests are therefore a public concern, and projecting the development of forests under changing environmental and societal conditions is crucial for developing sustainable forest management strategies [1, 2].

Recent climate models predict that the most likely evolution of Mediterranean basin is towards a hotter and drier climate, with a significant increase in fire hazard and occurrence. Greece is considered a "hot spot", not only because of its high sensitivity to changes in recent decades, such as the processes of rural depopulation, land abandonment and the reduction of traditional forest use, but also for the predicted climate change [3, 4]. According to recent climatic data $[5,6]$, increased heat waves events, when combined with droughts, can result in large and severe forest fires $[7,8]$. Climate projections for 2070-2100 confirm a significant increase of fire potential for Europe, an enlargement of fire prone areas and a lengthening of fire season [9].

Fire statistics show a significant increase in both the number of wildfires and the area burned in Greece. The number of fires doubled and the area burned tripled during the last few years (mainly after 1990) and several reasons have been speculated for this augmentation in wildfire activity, such as the changes in population activities, socioeconomic conditions, land use, fuel accumulation, drought frequency and duration [10]. The increase of the burned area demonstrates that the last few years' wildfires occurred in a more severe mode in terms of fire behavior parameters, such as fire size, fire rate of spread and fireline intensity, thus creating major difficulties in fire suppression efficiency [11]. Additionally, increased concern has been raised on issues related to the potential impact that climate change may have on the fire regime in ecosystems that are not fire-dependent [12, 13]. The evidence for this emerges from fires that are nowadays spreading over higher altitudes and northern latitudes. In these environments, forest ecosystems are not resilient to fire, since they have not been evolutionary exposed to its frequent action [14]. Dimitrakopoulos et al. [15] reported a statistically significant increase in the mean annual number of fires and the burned area in the relatively more humid and colder regions of Greece during the last few years. Additionally, laboratory studies revealed that fire-stricken low elevation forest species do not demonstrate higher flammability traits than the high elevation non fire-stricken species, and that the main factor of increased fire occurrence in high elevation Mediterranean forests could be attributed to climate change [16].

One of the most important forest species in high elevation forests of Greece is fir (Abies taxa) Among the fir forests occurring in the Mediterranean Basin, the endemic to Greece Abies cephalonica Loudon (Greek fir) can be found at medium and high altitude mountains of the continental Greece and in the islands of Cephalonia, Peloponnesos and Eubea. On the Greek mainland, the hybrid species of Abiesborisii-regis Mattf. occur, while at the northern range limit, the hybrid populations mostly resemble Abies alba Mill. and grow together with individuals of this species, while at the southern range limit they mostly resemble Abies cephalonica [17]. The total forest area for both Abies cephalonica and Abies-borisii-regis is estimated at almost 200,000 ha [18]. According to the European Forest Types classification scheme [19], these forests are included in category 6.10.6 'Mediterranean and Anatolian 
fir forest'. Figure 1 shows the spatial distribution of fir forests in Greece. Overall, fir dominated forests feature a comparatively low fire danger, since they mostly occur in areas with moderate to high rainfall. The high air relative humidity, along with the rather dense closure of fir stands which intercept radiation, results in relatively high moisture contents of surface fuels. This makes fire ignition and spread less severe and intense. However, there is some evidence that, under certain conditions, fir forests could became susceptible to intense fires. A prolonged drought period may be a prerequisite for such fires in fir forests. In contrast to broad-leaved and pine forests, where self-pruning is common, little branch-pruning occur in fir stands. Thus, there is a substantial ladder fuel from the forest floor to the tree crown, which increases the probability of crowning should a fire occur [20].
The effects of fire occurrence in high elevation forests of Greece became apparent in 2007 when more than 270,000 ha were totally burned and a large number of high altitude forest ecosystems were affected. A large fire on Parnitha Mountain, on the outskirts of the Athens urban area, destroyed approximately 2,180 ha of fir forest. During the same year, a fire in Tayetos Mountain burned 4,500 ha of Greek fir and Black pine forests [21]. Greek fir is vulnerable to fire since it does not produce serotinous cones and does not maintain a canopy seed bank when summer wildfires occur $[22,23]$.

Several studies which analyze forest and land managers' perspectives regarding the climate change risk in forest ecosystems exist [24-27]. However, knowledge on adaptive forest fire management under climate change is lacking

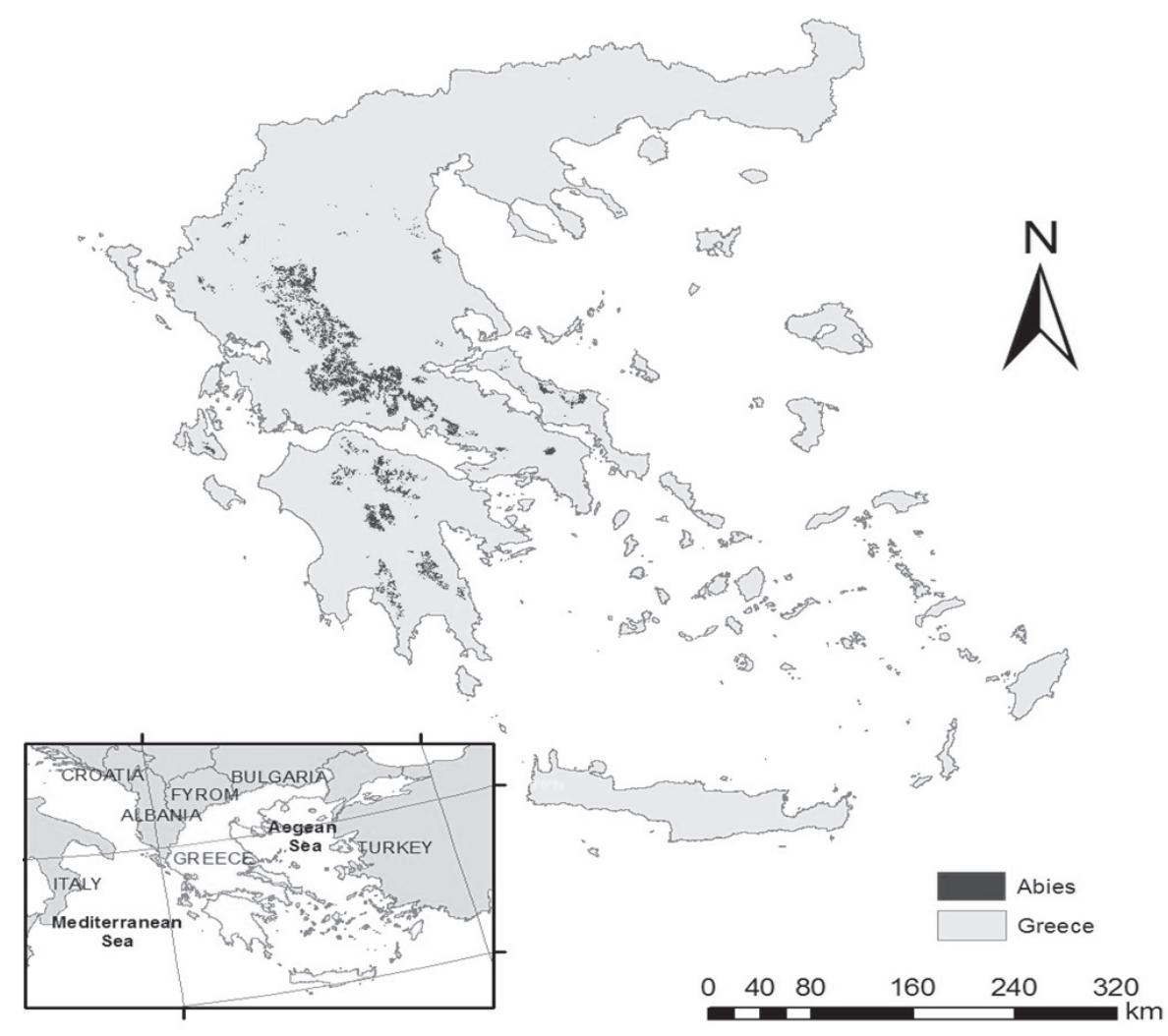

FIGURE 1. Geographical distribution of fir forests in Greece 
and/or is limited only to Mediterranean forest ecosystems [28]. Forest managers play a critical role in the adaptive capacity of forests to factors such as climate change and wildfire risk, since they are employed by key forest decision-making agencies. Consequently, their perceptions may be critically important in determining how forest fire management considerations are incorporated into forest management plans and policies under climate change. Documenting the perspectives of forest experts could therefore provide useful insights into the state of knowledge and practice on climate adaptation on fires within fir forest ecosystems [29,30].

The main objective of the current study is to present the results of a survey regarding the perceptions of forest managers in Greece about fire management needs and adaptation in fir forests under a changing climate.

\section{MATERIALS AND METHODS}

The respondents for this study were Greek forest managers employed in public forest management agencies. Therefore, the respondents represent people with an aboveaverage interest in climate change and an excellent understanding in wildfire risk and its potential implication for fir forest ecosystems. The perceived fire risk and management to fir forest ecosystems was assessed by means of a subset of scales previously identified as relevant to climate change and fire management.

The questionnaire consisted of four parts:

- Part A: Current status, knowledge gaps and needs (8 items)

- Part B: Fire prevention in fir forests under climate change (6 items)

- Part C: Fire suppression in fir forests under climate change (1 item)

- Part D: Post fire restoration and rehabilitation of fir forests under climate change (3 items).

The questionnaire was answered by conducting personal interviews and by visiting all forest authorities which manage fir forests in Greece. Respondents were asked to rate the importance of each of the adaptation options of forest fire management in fir forests under a changing environment, using a scale from 1 to $5(1=$ not important; $2=$ not so important; 3 =important; $4=$ =ery important; $5=$ most important). The duration of the interviews varied from $30^{\prime}$ to $1 \mathrm{~h}$ due to the flexibility of the survey and the effort made to deepen the understanding of personal views. In total, 63 forest experts answered the questionnaire from 43 different forest management units. The mean with its standard deviation (SD) and the coefficient of variation (CV) were calculated and presented.

\section{RESULTS AND DISCUSSION}

\section{Current Status, Knowledge Gaps and Needs}

In the beginning, the respondents were asked questions aimed at establishing their general attitudes and beliefs about climate change (Table 1). The responses to the attitudinal questions revealed that most of the respondents agreed that climate change which has already affected or may affect fir forests in the near future, is already happening and that climate change is a serious or a very serious problem. The respondents were also asked to report how well-informed they were about climate change. They claimed to be either moderately or wellinformed about these topics (mean: 3.08, SD: 0.93, CV: $30.2 \%$ ). Additionally, most of the respondents believe that the funding research regarding climate change and the guidelines for adaptation to fir forests are very important components for managing these ecosystems under a regional climate change.

To understand why the adaptation planning to climate change in fir forests is not taking place more widely, respondents were asked to rank the most important factors preventing them from planning the adaptation. Overall, budget and personnel constraints were the two most common answers as well as the two options with the highest rankings (Table 2a). Additionally, lack of information is also considered quite 
TABLE 1. General perspectives about climate change and fir forests

\begin{tabular}{|c|c|c|c|}
\hline Questions (Ratings 1-5) & Mean & $\begin{array}{l}\text { Standard } \\
\text { Deviation }\end{array}$ & $\begin{array}{l}\text { Coefficient of } \\
\text { Variation (\%) }\end{array}$ \\
\hline $\begin{array}{l}\text { a) Do you believe that climate change has } \\
\text { affected or may affect in the near future the fir } \\
\text { forests in your area? }\end{array}$ & 3.68 & 1.02 & 27.7 \\
\hline $\begin{array}{l}\text { b) How important do you consider the } \\
\text { adaptation of forest management in fir forests } \\
\text { after having taken account of climate change? }\end{array}$ & 3.95 & 0.84 & 21.3 \\
\hline $\begin{array}{l}\text { c) How well informed you feel are about climate } \\
\text { change in fir forests? }\end{array}$ & 3.08 & 0.93 & 30.2 \\
\hline $\begin{array}{l}\text { d) How important are the regulations of the } \\
\text { General Secretariat of Forests to provide issues } \\
\text { for adapting fir management in relation to } \\
\text { climate change? }\end{array}$ & 4.08 & 0.91 & 22.3 \\
\hline $\begin{array}{l}\text { e) In your opinion, how important is the } \\
\text { research on climate change in fir forests to be } \\
\text { financed by national and EU funds? }\end{array}$ & 4.46 & 0.79 & 17.7 \\
\hline
\end{tabular}

important (mean: 2.73, SD: $1.20, \mathrm{CV}: 43.9 \%$ ). To assess the perceptions of local vulnerability to climate change, the respondents were asked to rate the importance of five potential impacts of climate change on the fir forests managed by their office. The intent of these questions was to understand how managers were viewing climate change and fir forests in the context of their particular region. Five of the potential consequences that had been offered were: fire risk increase, fir decline and dieback, infestations by pathogens, insects' attacks and the decrease of timber production (Table 2b). The most important effect of climate change in fir forests was considered to be fir decline and dieback (mean: 4.15, SD.: 0.91, CV: 21.9\%) followed by infestations by pathogens and insects attack. This could be expected since the decline of Greek fir as a consequence of climate change in terms of drought has often been reported throughout Greece during the last three decades [31]. Fire risk and the decrease of timber production were perceived as the least moderately possible and believed to have moderate possibility of happening as a result of climate change in fir forests of their region. One of the main goals of this research was to identify the most important measures which have to be taken related to climate change adaptation of fir forests on the ground. The respondents were asked to rank the most important management strategies or plans to deal with the potential impacts from climate change in fir forests. The survey offered eight potential adaptation measures (Table 2c). In their opinion, immediate logging of infected trees (sanitary logging) was by far the most important adaptation measure. The limitation of grazing, the application of selective logging and the thinning, as well as the changes in species composition, were also rated as important. Sanitary logging (the removal and disposal of infected trees) is a common practice implemented at areas suffering from epidemic bark beetle or fungi outbreaks. However, during logging activities, the creation of irregular stand structure and gaps in the forest should be avoided, as sanitary logging can even cause alterations in stand structural complexity, community composition and species populations [32]. The limitation of grazing both by wild and domestic mammals is considered to be necessary for the protection of regeneration and soil resources [33]. Grazing has a negative impact on the understory as well as on the regeneration of species, as it is considered to be an important regulatory factor especially following disturbances, such as forest fire. Thus, the fencing of areas that are under regeneration 
TABLE 2. Perspectives of climate change as risk to fir forests

$$
\text { Perception (Ratings:1-5) }
$$

a) Which are the most important factors that prevent you from planning for adaptation in fir forests to climate change?
1) Budget constrains
4.29
0.85
19.8
2) Personnel constrains
4.28
0.84
19.6
3) Lack of information and knowledge
2.73
1.20
43.9
4) Not high priority in my responsibility area
2.13
1.19
55.8

b) Based on your knowledge, which are the most important impacts of climate change affecting fir forests in your responsibility area?

\begin{tabular}{llll}
\hline 1) Fire risk increase & 2.61 & 1.13 & 43.3 \\
2) Fir decline and dieback & 4.15 & 0.91 & 21.9 \\
3) Infestations by pathogens & 2.98 & 1.05 & 35.2 \\
4) Insects attack & 2.86 & 1.15 & 40.2 \\
5) Decreased timber production & 2.57 & 1.22 & 47.4 \\
\hline
\end{tabular}

c) What are the most important forest management measures need to be taken to adapt fir forests to climate change?

1) Immediate logging of infected trees (sanitary logging)

$\begin{array}{lll}4.35 & 0.90 & 20.7 \\ 3.16 & 1.40 & 44.3 \\ 1.88 & 1.17 & 62.2 \\ 3.31 & 1.19 & 35.9 \\ 2.95 & 1.34 & 45.4 \\ 2.47 & 1.10 & 44.5 \\ 2.62 & 1.20 & 45.8 \\ 3.47 & 1.19 & 34.3\end{array}$

2) Changes in species composition by introducing tolerant in climate change species

3) Irrigation of specific fir stands when necessary

4) Application of selective logging and thinning

5) Enhancement of regeneration (either natural regeneration or by seeding/planting)

6) Extension of rotation period

7) Thinning targeting to better balance of water in fir stands

8) Limitation of grazing

3.47

1.19

34.3

process and the adjustment and rationalization of grazing by domestic mammals or control of wild animals' populations are needed. The application of selective logging and thinning was important as recommended by the respondents. It has been found that they can reduce both interand intraspecific competition for water, light and nutrients and thus render species less vulnerable to the attacks of pathogens [34]. Moreover, water balance within the forest ecosystem is restored, and negative impacts from droughts and forest fire are mitigated [35].

\section{Fire Prevention in Fir Forests under Cli- mate Change}

Tables 3 and 4 present a series of questions that intend to elicit insights about general and specific adaptation to climate change measures for the prevention of forest fires in fir forests. Most of the responders indicated public awareness raising, fuel management and the strength of fire suppression in personnel and infrastructure as the most important general adaptation measures to climate change in fir forests. However, measures such as the update of fire weather index in the present climate conditions and the application of different silvicultural treatments (logging) in fir forests are also considered quite important (Table 3).

In order to gain a better insight into fire prevention adaptation measures in fir forests, the respondents were asked a series of more specific questions (Table 4). Information spots on TV and radio, the education of students in schools, 
TABLE 3. Perspectives of climate change and fire prevention to fir forests

\begin{tabular}{lccc}
\multicolumn{1}{c}{ Perception (Ratings:1-5) } & Mean & $\begin{array}{c}\text { Standard } \\
\text { Deviation }\end{array}$ & $\begin{array}{c}\text { Coefficient of } \\
\text { Variation (\%) }\end{array}$ \\
\hline $\begin{array}{l}\text { What in your opinion are the most important general adaptation measures for the prevention of forest } \\
\text { fires in fir forests in your area under climate change? }\end{array}$ & & \\
\hline $\begin{array}{l}\text { 1) Strengthening fire suppression in personnel } \\
\text { and infrastructure }\end{array}$ & 3.98 & 1.11 & 27.8 \\
2) Raising public awareness & 4.19 & 0.94 & 22.4 \\
3) Fuel management & 4.09 & 0.96 & 23.4 \\
4) Application of different logging techniques & 2.81 & 1.18 & 41.9 \\
5) Update of the fire weather and danger system & 2.98 & 1.19 & 39.9 \\
6) Technical and legislative measures & 2.73 & 1.12 & 41.1 \\
\hline
\end{tabular}

signs and information within the fir forests and the distribution of informative material for the visitors have been rated from important to very important specific fire prevention measures in terms of raising public awareness with ranking means varying from 3.30 to 4.60 . Fire prevention programs in Greece should be addressed to public awareness, since the $97 \%$ of the fire causes in the country are attributed to human activities such as arsons and negligence [10]. Forest managers strongly believe that the local population and the tourists should be educated about how a warmer climate may increase fire frequency, become aware of the threats of wildfires to the security and health of their families, as well as to private property and public infrastructures, and to learn how to reduce or mitigate these potential threats.

The respondents did not rate fuel management very important for reducing fire risk in the context of climate change in fir forests. This is mainly due to the fact that in most areas in Greece, fir forests are not managed intensively and another reason lies in the fact that fir forests are usually located within NATURA 2000 areas, where a number of restrictions on management practices in forest areas exist [36]. To assess the perceptions of adapting fuel management in fir forest to climate change, the respondents were asked to rate the importance of nine fuel management treatments on the fir forests managed by their office. According to the respondents, the options of thinning, pruning and slash removal after loggings were by far the most important fuel management adaptation measures. Understory removal, favoring the mixed stands with broadleaved species and clearing the dry grasses in fir forest stands were also rated as quite important by the responders. Thinning and pruning in conifer stands can substantially reduce fire potential, since they modify stand structure and prevent the spread of surface fire and crown fire activity [37], as well as increase the resistance to drought and insect attack [38]. On the contrary, fuel management strategies such as prescribed burning and controlled grazing were rated as less important although there are a lot of studies which highlight the importance of these two fuel management strategies in reducing fire potential. Prescribed burning has been widely used to reduce surface fuels and, thus, decrease fire hazard and fire severity [39]. In Europe, prescribed burning which has been carried out in western Mediterranean (Portugal, Spain) and which has also been proved as a fast and cheap method for reducing dead and live biomass, from an ecological perspective, surrogates the natural impact of low to medium intensity fires [40]. The respondents ranked prescribed burning as a less important fuel management strategy due to the fact that is not allowed in Greece, and, consequently, there is no such field experience. Moreover, they stated their concerns about the potential damage that might occur if such fires escaped, which seemed to far outweigh any benefit they might offer. A rational fuel management in fir forests under a changing climate is essential for combining both surface 
(understory removal, controlled grazing etc.) and canopy fuel treatments (thinning, pruning). The combination of these fuel treatments must be followed by the removal of residues from logging and thinning. Otherwise, the contribution of the canopy fuel to the surface fuelbed could easily lead to crown ignition. The need of raising public awareness and the applying of fuel management techniques were also considered the most important climate change adaptive fire prevention measures by the respondents in a similar work, which referred to Mediterranean low elevation and fire stricken forests [28]. The authors stated different priorities in adaptive fire management options among several countries in Mediterranean basin. Nevertheless, their survey indicated that there is a need for an integrated fire management. The respondents also rated as important the application of selection cuttings and irregular shelterwood cuttings for preventing severe fire occurrence in fir forests. They justified their opinion by stating that these types of logging focus on water balance improvement and at drought effects mitigation and, sequentially, they would strengthen fir forests resistance against wildfires.

The respondents were also asked to rank the most important fire detection measures that should be adapted for fire prevention strategies in fir forests. Although a lot of new technologies (remote sensing, thermal sensors, and fire weather systems) exist, they ranked as the most important measures the traditional ones, such as the surface patrols in the forests and the fire observation towers. The application of new technology fire detection systems in Greece is limited, and operated mainly in local level, while robust evaluation is lacking. Recent works seem promising [41], but a long term evaluation is needed in order to make them widely applicable in an operational basis.

In Greece, technical and legislative measures are very important in fire prevention due to the strong influence of socioeconomic factors and changes which occurred recently and affected fire occurrence in the country [10]. The respondents were asked to rank the most important technical and legislative strategies or plans to deal with fire prevention in fir forests under climate change. The survey offered eleven potential adaptation measures (Table 4e). According to the respondents, the options of the maintenance and expansion of forest road network and the creation of water trunks were by far the most important adaptation measures. The development of fire management plans, preventive actions in electric power poles and networks of firefighting hydrants were also rated as important. Greece has a long tradition in fire suppression practices and all the above mentioned measures are considered important in fire prevention mainly in facilitating fire suppression tactics for reducing initial attack time. Fir forests are mainly located in mountainous and remote areas, and most of the responders stated that technical measures and the improvement of the infrastructure within and around the forest stands will substantially improve fire management under the expected climate change. Other adaptive measures such as the improvement of brake materials on railways, the improvement of the machines which use internal combustion engines and the creation of safety smoking devices for use in bee-hives were rated less important. This can be attributed to the different existing agricultural and social conditions among the various fir ecosystems in the country.

\section{Fire Suppression in Fir Forests under Climate Change}

Table 5 presents the responds of the forest managers' perspectives and fire suppression in fir forests under climate change. To understand the low effectiveness of fire suppression forces in Greece, the respondents were asked to rank the most important factors which should be taken into consideration for a successful firefighting in fir forests. Overall, the establishment of a new firefighting organization and the improvement of coordination among all involved parties during fire suppression were the two most common answers as well as the two options with the highest rankings (Table 5). Additionally, the improvement of firefighters' and volunteers' training was reported as an important factor (mean: 3.80, SD: 1.10, CV: 29.2\%). The 
TABLE 4. Perspectives of specific prevention measures for adaptation of fir forests to fires under climate change

Perception (Ratings:1-5)

Mean $\begin{array}{ll}\text { Standard } & \text { Coefficient of } \\ \text { deviation } & \text { Variation (\%) }\end{array}$

a) What in your opinion are the most important adaptation measures for the information and awareness of forest fires in fir forests in your area under climate change?
1) Informative Spots on TV and radio
3.94
0.96
24.3
2) Education of students in the schools
4.60
0.75
16.3
3) Signs and information within the forests
3.53
1.20
33.9
4) Distribution of informative material to visitors
$3.30 \quad 1.19$
36.1

b) What in your opinion are the most important adaptation measures for fuel management in fir forests in your area under climate change?
1) Pruning
3.59
1.29
35.9
2) Thinning
3.77
1.15
30.5
3) Understory removal
3.20
1.23
38.4
4) Fuelbreaks
2.61
1.40
53.6
5) Controlled grazing
2.87
1.22
42.5
6) Prescribed burning
1.92
1.08
56.2
7) Favoring of mixed stands with broadleaved species
3.11
1.35
43.4
8) Slash removal
3.44
1.17
34.1
9) Clearing of dry grasses to prevent fuel accumulation
3.09
1.43
46.2

c) What in your opinion is the most important way of implementing logging in fir forests in your area to prevent forest fires under climate change?
1) Clear-cuttings
1.12
0.55
49.1
2) Strip shelterwood cuttings
2.04
0.99
48.5
3) Irregular shelterwood cuttings
3.65
1.09
29.8
4) Selection cuttings
4.28
0.97
22.6

d) What in your opinion are the most important fire detection measures for the prevention of forest fires in fir forests in your area under a climate change?
1) Surface patrols in the forests
4.50
0.79
17.5
2) Fire detection from the air
3.06
1.20
39.2
3) Fire towers
4.09
1.10
26.8
4) Fire weather and danger systems
3.04
1.30
42.7
5) Systems and networks of thermal detection sensors
3.06
1.35
44.1

e) What, in your opinion, are the most important technical and legislative measures to prevent fires in fir forests in your area under climate change?

\begin{tabular}{llll}
\hline 1) Development of fire management plans & 4.04 & 1.05 & 25.9 \\
2) Maintenance and expansion of forest road network & 4.42 & 0.81 & 18.3 \\
3) Creation of water tanks & 4.27 & 0.72 & 16.8 \\
4) Networks of firefighting hydrants & 3.79 & 1.19 & 31.3 \\
5) Building heliports near fir forests & 2.60 & 1.31 & 50.3 \\
6) Improvement of legislation regarding land use and property & 3.33 & 1.19 & 35.7 \\
7) Improvement of brake materials on railways & 1.90 & 1.01 & 53.1 \\
$\begin{array}{l}\text { 8) Improvement of machines that use internal combustion engines } \\
\text { (e.g., chainsaw) }\end{array}$ & 2.22 & 1.02 & 45.9 \\
9) Create safety smoking devices for use in bee-hives & 2.46 & 1.05 & 42.6 \\
10) Rules and regulations for citizens safety in fir forests during & 3.61 & 1.17 & 32.4 \\
$\quad$ fire season & & & \\
11) Preventive actions in electric power poles (insulated wire, & 4.03 & 1.18 & 29.2 \\
$\quad$ pruning trees touching the wires, cleaning around transformers)
\end{tabular}


establishment of a new firefighting organization has received the highest ranking of importance among the responders (mean: 4.47, SD: 1.01, CV: $22.5 \%)$. This is not a surprising finding. In 1998, the Greek government decided to transfer the responsibility of forest firefighting from the Forest Service to the Fire Service with no provision for cooperation between the personnel of the Forest and the Fire Services at all levels. Over the next years, Greece faced large number of devastating fire events (1998, 2000, 2007 and 2009) and that decision is still in dispute in terms of its effectiveness by the forest managers, since firefighting officers did not have any experience on forest fire incidents in the past. However, at the same time, forest managers believe that the transfer of firefighting responsibility again to Forest Service is less important (mean: 2.74, SD: 1.76, CV: 64.2\%). Moreover, the standard deviation and the coefficient of variation for this question presented high values, suggesting greater disagreement among respondents. Currently, as time passes since the deprivation of forest fire responsibility from the forest service, the collective knowledge and mostly the experience of its personnel on forest fires, is being lost. Furthermore, approximately one fourth of its personnel as well as many pieces of equipment (vehicles, radios etc.) were moved to the Fire Service without any replacement. This is negative both in regard to better firefighting efficiency in the future, as well as in regard to use of backfire technique during fire suppression (mean 2.38, SD: 1.15, CV: $48.3 \%)$. In Greece, during fire events, a number of organizations (Fire Service, the General Secretariat for Civil Protection, the Police, the Air Force, the Army, municipalities and other local authorities) are involved without having clear duties and responsibilities. This fact made the fire suppression system very complex and ineffective [42]. The respondents claimed that the improvement of coordination among all involved parties during fire suppression is very important for suppressing fires in fir forests under climate change (mean: 4.44, SD: $0.83, \mathrm{CV}$ : $18.6 \%$ ).

Although, a lot of different fire suppression schemes exist among the Mediterranean countries, forest experts and managers recognize the improvement of firefighting coordination as the most important adaptation measure in forest fire management under climate change [28]. Fire suppression organization in Mediterranean basin has failed to mitigate extreme fire seasons (e.g., Portugal 2003, 2005; Greece and Italy 2007), despite its increased funding, a large number of permanent and seasonal personnel and the infrastructure in terms of ground and aerial means in the last few years. For that reason, forest managers strongly highlighted that fire prevention activities are the most important component of forest fire management under climate change compared to fire suppression. This is also in agreement with a similar study in the area [43].

\section{Post Fire Restoration and the Rehabili- tation of Fir Forests under Climate Change}

Table 6 summarizes the responses to the questions about perceived post fire management to fir forests under climate change. The respondents perceived the protection of fir natural regeneration (mean: 4.36, SD: 0.92, CV: $21.1 \%$ ) and the protection of soils (mean: 4.31, SD: $1.06, \mathrm{CV}: 24.5 \%$ ) as having the most significant importance (Table 6.a). The degree to which the respondents felt that post fire seeding and planting would be a good choice to climate change in fir forests exceeded the midpoint value (mean 3.25, SD: 1.24, CV: $38.1 \%$ ). The ratings for the degree to which the respondents felt that post fire logging of standing dead trees is an important post fire rehabilitation measure in fir forests under climate change were near the midpoint (mean: 2.81, SD: 1.25, CV: $44.4 \%$ ). Post fire logging poses a large debate among fire scientists and managers worldwide. After standreplacing wildfires, there is often considerable conflict when post-fire logging is proposed. Harvesting fire-killed trees immediately after wildfire can provide economic benefits to local communities and may reduce risks of insect and disease outbreaks that can kill additional trees [44]. However, there is concern that the ecological costs of post-fire logging may outweigh the economic benefits [45]. 
TABLE 5. Perspectives of climate change and fire suppression to fir forests

$$
\text { Perception (Ratings:1-5) }
$$

Mean

Standard Deviation

Coefficient of Variation (\%)

What, in your opinion, are the most important measures for fire suppression in the fir forests of your area under climate change?
1) Transfer of firefighting responsibility to forest service
2.74
1.76
64.2
2) Establishment of a new firefighting organization
4.47
1.01
22.5
3) Use of backfire during fire suppression operations
2.38
1.15
48.3
4) Improvement in training of firefighters and volunteers
3.80
1.11
29.2
5) Improvement in coordination of all involved parties during fire suppression
$4.44 \quad 0.83$
18.6

TABLE 6. Perspectives of post fire management measures for adaptation of fir forests under climate change

$$
\text { Perception (Ratings:1-5) }
$$

Mean

Standard Coefficient of Deviation Variation (\%)

a) What in your opinion are the most important post fire rehabilitation measures in fir forests in your area under climate change?
1) Protection of soil resources
4.31
1.06
24.5
2) Protection of natural regeneration
4.36
0.92
21.1
3) Logging of standing dead trees
2.81
1.25
44.4
4) Seeding/planting
3.25
1.24
38.1

b) What in your opinion are the most important post fire soil protection measures in fir forests in your area under climate change?
1) Contour-felled logs
4.01
1.11
27.6
2) Contour branch barriers
3.95
1.08
27.3
3) Log check dams
3.77
1.16
30.7
4) Concreted dams
1.82
0.96
52.7

c) What, in your opinion, are the most important post fire regeneration measures in fir forests in your area under climate change?

1) Prohibition of grazing within the burned areas

$\begin{array}{lll}4.60 & 0.81 & 17.6 \\ 4.57 & 0.91 & 19.9 \\ 4.22 & 1.18 & 27.9 \\ 2.14 & 1.11 & 51.8\end{array}$

3) Accurate burned area mapping

3.65

1.15

31.5

17.6
19.9
27.9
51.8
31.5

The respondents were also asked to rank the most important factors which should be taken into consideration for successful post fire soil protection in fir forests. Overall, the establishment of contour-felled logs, contour branch barriers and the log check dams were the two most common answers as well as the two options with the highest rankings (Table $6 \mathrm{~b}$ ). On the contrary, the establishment of concreted dams was re- ported as a less important factor (mean: 1.82, SD: 0.86, CV: $52.7 \%)$ mainly due to ecological restrictions. Effectiveness assessment of various site rehabilitation treatments to reduce post fire soil erosion is critical in forest ecosystems. Based on their experience the responders suggested the contour-felled logs and contour branch barriers as the most important ones. However, there are studies which state that contour-felled 
logs are effective in trapping sediments on steep slopes [46] and for small rain events [47], while they are ineffective in other slopes and for large storms [48]. To assess the perceptions of adapting post fire regeneration of fir forest to climate change, the respondents were asked to rate the importance of five post fire regeneration treatments on the fir forests managed by their office (Table $6 \mathrm{c}$ ). The respondents suggested prohibition of grazing within the burned areas, declaring the reforestation of all burned areas and accurate burnt areas mapping as the most important measures. The degree to which the respondents felt that post fire facilitation of fir regeneration by introducing other species for favoring its natural regeneration would be a good choice to climate change in fir forests exceeded the midpoint value (mean 3.65, SD: 1.15, CV: $31.5 \%$ ). The latter choice has been justified by the fact that fir species are shadedemanding with a low growth rate during its early stages, making its post fire establishment difficult, even artificially. Moreover, fir species are obligate seeders, while the seeds produced ripen in autumn [23] thus, after a fire event; there are no mature seeds to ensure regeneration. This fact could lead to an increased risk of non-potential reestablishment of the burned forest due to regeneration failure, and burned forests are likely to turn into scrublands and/or grasslands. Therefore, their natural post-fire recovery is limited, and strongly dependent on seed dispersal from neighboring unburned individuals or patches [14]. More recent results also showed that early post fire regeneration succession in burned fir forests of Greece is characterized by species adapted to wildfires such as shrubs and herbaceous [49]. Furthermore, the respondents rated as less important to leave the standing burnt trees in order to facilitate the natural regeneration of fir seedlings (mean: 2.14, SD: $1.11, \mathrm{CV}: 51.8 \%)$. Most of the respondents stated that as standing dead trees would start to decompose; they may become more fractured and flammable, increasing the duration of flaming and smoldering combustion, and increasing tree mortality and soil heating in potential future fire events.

\section{CONCLUSIONS}

The perceptions of forester managers in Greece were investigated on the issues of climate change, wildfires and adaptive measures facing the increased risk of fir forests. The survey consisted of a broad set of questions covering all aspects of fire management such as fire prevention, fire suppression and post fire treatments, and it had been conducted in all forest units which manage fir forests in the country. Increased fire risk was rated as a quite important issue in fir forests during the last years, while adapting options to climate change are not implemented mainly due to budget and personnel constrains. According to forest experts, fire prevention in fir forests under climate change should be focused on public awareness and fuel management. Nevertheless, the survey results indicate that there is also a need for specific fire prevention measures such as the type of logging activities and other technical measures. The result of this survey highlighted the need for the establishment of a new firefighting organization and for the better coordination of all involved parties during fire suppression. The main reason for such responds is likely to be the pitfalls and problems which the current fire suppression system in the country shows. An improved communication between science and management through the funding research has also been rated as critical for supporting forest managers in their response to climate change, especially in post fire management of fir forests

\section{Acknowledgments}

We thank the forest managers who took the time to answer our survey and contribute their knowledge to this study. Their insights provided depth and clarity to our study. This research has been co-financed by the European Union (European Social Fund - ESF) and Greek national funds through the Operational Program "Education and Lifelong Learning" of the National Strategic Reference Framework (NSRF) - Research Funding Program: ARCHIMEDES III. Investing in knowledge society through the European Social Fund. 


\section{REFERENCES}

1. DANIELS L, MAERTENS T, STAN A, MCCLOSKEY S, COCHRANE J, GRAY R 2011 Direct and indirect impacts of climate change on forests: three case studies from British Columbia. Can J Plant Pathol 33 (2): 108-116. DOI: http://dx.doi.org/10.1080/0 7060661.2011.563906

2. PAPADOPOL C 2000 Impacts of climate warming on forests in Ontario: Options for adaptation and mitigation. For Chron 76 (1): 139-149

3. GIANNAKOPOULOS $C$, LE SAGER $P$, BINDI $M$, MORIONDO M, KOSTOPOULOU E, GOODESS C 2009 Climatic changes and associated impacts in the Mediterranean resulting from a $2^{\circ} \mathrm{C}$ global warming. Glob Planet Change 68 (3): 209-224. DOl: http://dx.doi.org/10.1016/j. gloplacha.2009.06.001

4. KOUTSIAS N, XANTHOPOULOS G, FOUNDA D, XYSTRAKIS F, NIOTI F, PLENIOU M, MALLINIS G, ARIANOUTSOU M 2013 On the relationships between forest fires and weather conditions in Greece from long-term national observations (1894-2010). Int J Wildland Fire 22 (4): 493-507. DOI: http://dx.doi.org/10.1071/WF12003

5. FOUNDA D, GIANNAKOPOULOS C 2009 The exceptionally hot summer of 2007 in Athens, Greece - A typical summer in the future climate? Glob Planet Change 67 (3-4): 227-236. DOI: http://dx.doi. org/10.1016/j.gloplacha.2009.03.013

6. TOLIKA K, MAHERAS P, TEGOULIAS I 2009 Extreme temperatures in Greece during (2007) Could this be a "return to the future"? Geophys Res Lett 36: L10813. DOI: http://dx.doi. org/10.1029/2009GL038538

7. GOOD P, MORIONDO M, GIANNAKOPOULOS C, BINDI M 2008 The meteorological conditions associated with extreme fire risk in Italy and Greece: relevance to climate models studies. Int J Wildland Fire 17 (2): 1-11. DOI: http://dx.doi. org/10.1071/WF07001

8. MORIONDO $M$, GOOD P, DURAO R, BINDI $M$, GIANNAKOPOULOS C, CORTE-REAL J 2006 Potential impact of climate change on fire risk in the Mediterranean area. Clim Res 31 (1): 85-95. DOI: http://dx.doi.org/10.3354/cr031085

9. DEQUE M, MARQUET P, JONES R 1998 Simulation of climate change over Europe using a global variable resolution general circulation model. Clim Dyn 14 (3): 173-189. DOI: http://dx.doi. org/10.1007/s003820050216
10. DIMITRAKOPOULOS A, MITSOPOULOS I 2006 Thematic report on forest fires in the Mediterranean Region. In: Vuorinen A (ed) Global Forest Resources Assessment, Forest Fire Management Working Paper 8. Food and Agriculture Organization of the United Nations (FAO), Rome, Italy $43 \mathrm{p}$

11. MITSOPOULOS I, MALLINIS G, KARALI A, GIANNAKOPOULOS C, ARIANOUTSOU M 2014 Mapping fire behaviour in a Mediterranean landscape under different future climate change scenarios. In: International Conference ADAPTtoCLIMATE, Nicosia, Cyprus. 27-28 March 2014.

12. PAUSAS J 2004 Changes in fire and climate in the Eastern Iberian Peninsula (Mediterranean Basin). Clim Chang 63 (3): 337-350. DOI: http://dx.doi. org/10.1023/B:CLIM.0000018508.94901.9c

13. PIÑOL J, TERRADAS J, LLLORET F 1998 Climate warming, wildfire hazard and wildfire occurrence in coastal eastern Spain. Clim Chang 38 (3): 345-357. DOI: http://dx.doi.org/10.1023/A:1005316632105

14. ARIANOUTSOU M, CHRISTOPOULOU A, TOUNTAS T, GANOU E, KAZANIS D, BAZOS I, KOKKORIS I 2010 Effects of fire on high altitude coniferous forests of Greece. In: Viegas D (ed) VI ${ }^{\text {th }}$ international conference on forest fire research, Coimbra, Portugal, 15-18 November 2010

15. DIMITRAKOPOULOS A, VLAHOU M, ANAGNOSTOPOULOU C, MITSOPOULOS I 2011 Impact of drought on wildland fires in Greece; Implications of climatic change? Clim Chang 109 (3-4): 331-347. DOI: http://dx.doi.org/10.1007/ $\underline{\text { s10584-011-0026-8 }}$

16. DIMITRAKOPOULOS A, MITSOPOULOS I, KALIVA A 2013 Comparing flammability traits among firestricken (low elevation) and non-fire-stricken (high elevation) conifer forest species of Europe: A test of Mutch hypothesis. Forest Syst 21 (1): 133-137. DOI: http://dx.doi.org/10.5424/fs/2013221-02475

17. MITSOPOULOS D, PANETSOS C 1987 Origin of variation in fir forests in Greece. Silvae Genet 36: 1-15

18. AUSSENAC G 2002 Ecology and ecophysiology of circum-Mediterranean firs in the context of climate change. Ann For Sci 59 (8): 823-832. DOI: http://dx.doi.org/10.1051/forest:2002080 
19. EUROPEAN ENVIRONMENTAL AGENCY (EEA) 2007 European forest types. Categories and Types for sustainable forest management reporting and policy. EEA Technical report no 9, 2nd edn. Copenhagen, Denmark, 111 p. URL: http://www. env-edu.gr/Documents/European $\% 20$ forest $\% 20$ types.pdf (10 January 2015)

20. FURYAEV V, WEIN R, MACLEAN D 1983 Fire Influences in Abies -dominated forests. In: Wein $R$, MacLea $D$ (eds) The role of fire in Northern Circumpolar ecosystems. Wiley Chichester, England

21. ARIANOUTSOU M, CHRISTOPOULOU A, GANOU E, KOKKORIS I, KAZANIS D 2009 Post-fire response of the Greek endemic Abies cephalonica forests in Greece: the example of a NATURA 2000 site in Mt Parnitha National Park. In: Miko L, Boitani L (eds) 2nd European congress of conservation biology, Prague, Czech Republic, 1-5 September 2009. Czech University of Life Sciences, Faculty of Environmental Sciences, Prague, Czech Republic

22. HABROUK A, RETANA J, ESPELTA J 1999 Role of heat tolerance and cone protection of seeds in the response of three pine species to wildfires. Plant Ecol 145 (1): 91-99. DOI: http://dx.doi. org/10.1023/A:1009851614885

23. POLITI P, GEORGHIOU K, ARIANOUTSOU M 2011 Reproductive biology of Abies cephalonica Loudon in Mount Aenos National Park, Cephalonia, Greece. Trees - Struct Funct 25 (4): 655-668. DOI: http://dx.doi.org/10.1007/s00468-011-0542-1

24. ARCHIE K, DILLING L, MILFORD J, PAMPEL F 2012 Climate change and western public lands: a survey of U.S. federal land managers on the status of adaptation efforts. Ecol Soc 17 (4): 20. DOI: http:// $\mathrm{dx}$.doi.org/10.5751/ES-05187-170420

25. OGDEN A, INNES L 2009 Application of structured decision making to an assessment of climate change vulnerabilities and adaptation options for sustainable forest management. Ecol Soc 14 (1): 11 URL: http://www.ecologyandsociety.org/vol14/ iss1/art11/ (5 December 2014)

26. WILLIAMSON T, WATSON D 2010 Assessment of community preference rankings of potential environmental effects of climate change using the method of paired comparisons. Clim Chang 99 (3): 589-612. DOI: http://dx.doi.org/10.1007/ s10584-009-9656-5

27. WILLIAMSON T, PARKINS J, MCFARLANE B 2005 Perceptions of climate change risk to forest ecosystems and forest-based communities. For Chron 81 (5): 710-716
28. RAFTOYANNISY, NOCENTINI S, MARCHIE, CALAMA $R$, SAINZ C, GARCIA GUEMES L, PILAS I, PERIC S, AMARAL J, PAULO A, et al. 2014 Perceptions of forest experts on climate change and fire management in European Mediterranean forests. iForest 7: 33-41. DOI: http://dx.doi.org/10.3832/ ifor0817-006

29. BULLOCK R, HANNA K, SLOCOMBE D 2009 Learning from community forestry experience: Challenges and lessons from British Columbia. For Chron 85 (2): 293-304. DOI: http://dx.doi. org/10.5558/tfc85293-2

30. KALABOKIDIS $K$, IOSIFIDES T, HENDERSON $M$, MOREHOUSE B 2008 Wildfire policy and use of science in the context of a socio-ecological system on the Aegean Archipelago. Environ Sci Policy 11 (5): 408-421. DOI: http://dx.doi.org/10.1016/j. envsci.2008.01.006

31. RAFTOYANNIS Y, SPANOS I, RADOGLOU K 2008 The decline of Greek fir (Abies cephalonica Loudon): Relationships with root condition. Plant Biosyst 142 (2): 386-390. DOI: http://dx.doi. org/10.1080/11263500802151017

32. LINDENMAYER $D$, NOSS $R 2006$ Salvage logging, ecosystem processes, and biodiversity conservation. Conserv Biol 20 (4): 949958. DOI: http://dx.doi.org/10.1111/j.15231739.2006.00497.x

33. GILL R 1992 A review of damage by mammals in north temperate forests. Impact on trees and forests. Forestry 65 (4): 363-388. DOI: http:/l dx.doi.org/10.1093/forestry/65.4.363-a

34. SPIECKER H 2003 Silvicultural management in maintaining biodiversity and resistance of forests in Europe - Temperate zone. J Environ Manage 67 (1): 55-65. DOI: http://dx.doi.org/10.1016/S03014797(02)00188-3

35. SABATÉ S, GRACIA C, SÁNCHEZ A 2002 Likely effects of climate change on growth of Quercus ilex, Pinus halepensis, Pinus pinaster, Pinus sylvestris and Fagus sylvatica forests in the Mediterranean region. For Ecol Manage 162 (1): 23-37. DOI: http://dx.doi.org/10.1016/S03781127(02)00048-8

36. EUROPEAN UNION 2012 Guidelines on Climate Change and Natura 2000 Dealing with the impact of climate Change on the management of the Natura 2000 Network of areas of high biodiversity value. European Commission, 145 p. DOI: http:// dx.doi.org/10.2779/29715 
37. STEPHENS S 1998 Evaluation of the effects of silvicultural and fuels treatments on potential fire behavior in Sierra Nevada mixed conifer forests. For Ecol Manage 105 (1-3): 21-35. DOI: http:/l dx.doi.org/10.1016/S0378-1127(97)00293-4

38. DALE V, JOYCE L, MCNULTY S, NEILSON R, AYRES $M$, FLANNIGAN M, HANSON P, IRLAND L, et al. 2001 Climate change and forest disturbances. BioScience 51 (9): 723-734. DOI: http://dx.doi. org/10.1641/0006-3568(2001)051[0723:CCAFD]2 $.0 . \mathrm{CO} ; 2$

39. JOHNSON K, SESSIONS J, FRANKLIN J, GABRIEL J 1998 Integrating wildfire into strategic planning for Sierra Nevada forests. J For 96 (1): 42-49

40. FERNANDES P, DAVIES G, ASCOLI D, FERNANDEZ C MOREIRA F, RIGOLOT E, STOOF C, VEGA J, et al. 2013 Prescribed burning in southern Europe: developing fire management in a dynamic landscape. Front Ecol Environ 11: 4-14. DOI: http://dx.doi.org/10.1890/120298

41. KONTOES C, KERAMITSOGLOU I, PAPOUTSIS I, SIFAKIS N, XOFIS P 2013 National scale operational mapping of burnt areas as a tool for the effective development of wildfire management strategy. Sensors 13 (8): 11146-11166. http://dx.doi. org/10.3390/s130811146

42. XANTHOPOULOS G 2000 Forest fires in Greece. International Forest Fire News 23: 76-84

43. MOREIRA F, VIEDMA O, ARIANOUTSOU M, CURT T, KOUTSIAS N, RIGOLOT E, BARBATI A, CORONA $P$, et al. 2011 Landscape-wildfire interactions in southern Europe: Implications for landscape management. J Environ Manage 92 (10): 2389-2402. DOI: http://dx.doi.org/10.1016/j. jenvman.2011.06.028
44. BROWN J, REINHADT E, KRAMER E 2003 Coarse woody debris: managing benefits and fire hazard in the recovering forest. USDA Forest Service General Technical Report RMRSGTR- 105. Rocky Mountain Research Station, Ogden, UT, USA, 16 p. URL: http://www.fs.fed.us/rm/pubs/rmrs gtr105. pdf (11) December 2014)

45. MCIVER J, STARR L 2001 A literature review on the environmental effects of postfire logging. West $J$ Appl For 16 (4): 159-168

46. GAGARI P, LYRINTZIS G, BALOUTSOS G, XANTHOPOULOS G 2001 Contribution of log erosion barriers to soil protection and vegetation recovery after wildfire in a Pinus halepensis forest, in Greece. In: Radoglou K (ed) Proceedings International Conference of Forest Research: A Challenge for an Integrated European Approach, Thessaloniki, Greece, 27 August-1 September 2001.

47. ROBICHAUD $P$, WAGENBRENNER J, BROWN $R$, WOHLGEMUTH P, BEYERS B 2008 Evaluating the effectiveness of contour-felled log erosion barriers as a post-fire runoff and erosion mitigation treatment in the western United States. Int J Wildland Fire 17 (2): 255-273. DOI: http://dx.doi. org/10.1071/WF07032

48. MYRONIDIS D, EMMANOULOUDISD, MITSOPOULOS I, RIGGOS E 2010 Soil erosion potential after fire and rehabilitation treatments in Greece. Environ Model Assess 15 (4): 239-250. DOI: http://dx.doi. org/10.1007/s10666-009-9199-1

49. GANATSAS P, DASKALAKOU E, PAITARIDOU D 2012 First results on early post-fire succession in an Abies cephalonica forest (Parnitha National Park, Greece). iForest 5: 6-12. DOI: http://dx.doi. org/10.3832/ifor0600-008

(C) 2015 by the Croatian Forest Research Institute. This is an Open Access paper distributed under the terms of the Creative Commons Attribution License (http://creativecommons.org/licenses/by/4.0). 